\title{
BLOOD GROUPING ON MOBILISATION AND IN THE FIELD
}

\author{
Colonel HUGH C. JEFFREY, \\ M.B., M.R.C.P.(Edin.), F.C.Path, D.T.M.\&H., Late R.A.M.C. \\ Royal Army Medical College, Millbank*
}

IT has been argued in a previous paper (Jeffrey, 1962) that transfusion arrangements for mass casualties under conditions of nuclear warfare should be based on the pre-grouping of all Army personnel by meticulous laboratory procedures. In the field, blood could then be taken off homologous donors as required and transfused without further laboratory control.

If, however, mobilisation was rapid, the ideal of complete pre-grouping by accepted laboratory standards, which are time-consuming, might not be attained; if non-Army donors, too, were used in the field, they may not be pre-grouped. There is hence a requirement for some simple method of rapid blood-grouping, as foolproof as possible, to meet these two possible situations.

In the absence of full laboratory facilities, it would appear that the only realistic approach to grouping in such circumstances is the technique of testing cells for antigens only, however unacceptable such a procedure may be for ordinary peacetime purposes. At present reliance for field grouping is placed on a set using the technique of Anti-A and Anti-B sera on a tile. $R$ h grouping is not included as a routine as it is only considered essential in the field for female personnel or men with a previous history of transfusion. No provision has yet been made for pre-grouping on mobilisation if time does not permit usual methods.

Eldon $(1955,1956)$ described a method of cell grouping on cards containing dried Anti-A, Anti-B and Anti-D sera. The aim of this paper is to discuss in detail the value of these cards in comparison with the present method of blood grouping in the field.

\section{Comparison of the Army Blood-Grouping Set and Eldon Cards}

Simplicity in Use. The basic requirements for grouping by the two methods are illustrated in Figure 1. Steps in grouping with the Army blood-grouping set include reconstitution of the two dried antisera with saline, transferring these to marked vials, preparation of a red cell suspension in two wells in the porcelain tile (which have to be marked with means of identification of the patient as well as the appropriate antiserum), adding the antisera, rocking to mix and reading for agglutination in 10-15 minutes time. Steps in grouping with Eldon cards include solution of the dried sera in the panels with tap water, addition of drops of whole blood, mixing by tilting and reading for agglutination in 3 minutes.

It is evident that the Eldon card method requires considerably fewer items of equipment and involves fewer steps in operation.

Rapidity. The preparation of the reagents in both methods takes some 5 minutes; final readings are made 10-15 minutes after the blood is first mixed with the antisera in the conventional tile method, after 3 minutes with the card technique.

*Now Military Hospital, Catterick Camp, Yorks. 
Documentation. In grouping by wet antisera, the slide or tile must be marked with the patient's or donor's name(s) and the spaces for the antisera labelled appropriately. There is but little space (see Figure 1) on the tile provided for such particulars and if

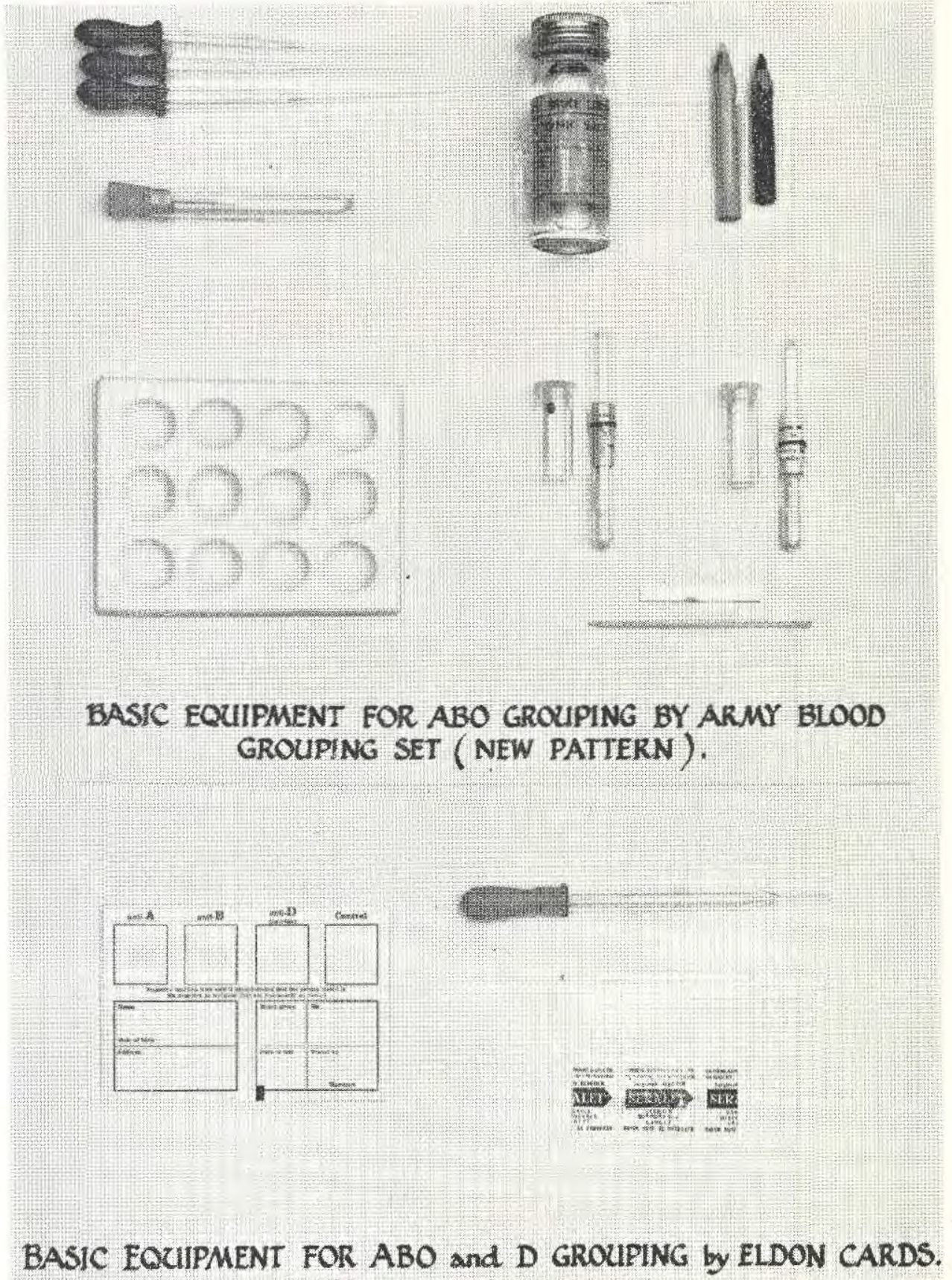

Fig. 1 
more than one grouping is being performed at the one time, it is evident that clerical errors can arise readily. The group, when read, must be recorded somewhere and again it is only human that errors may arise here.

With Eldon cards the spaces containing the antisera are already labelled and the particulars of the individual can be added to the card itself in the interval between adding the blood and commencing mixing. When the group has been read and recorded a permanent record is available without transfer of particulars to another document. If the panels are protected by Sellotape immediately when dry, a second, visual check is available any time in the future. If these procedures are carried out with the card beside the person being grouped, this system of documentation is well-nigh foolproof.

Reading results. Experience has shown that with the tile technique the density of cell suspension is critical. Reading for agglutination often requires an expert. The Eldon card gives clear-cut results with a wider latitude in the relative quantities of reagents. Photographs of cards illustrating grouping results are shown in Figure 2. (It may be noted that the group in eard 3 was actually $\mathrm{A}_{2} \mathrm{~B}$ ).

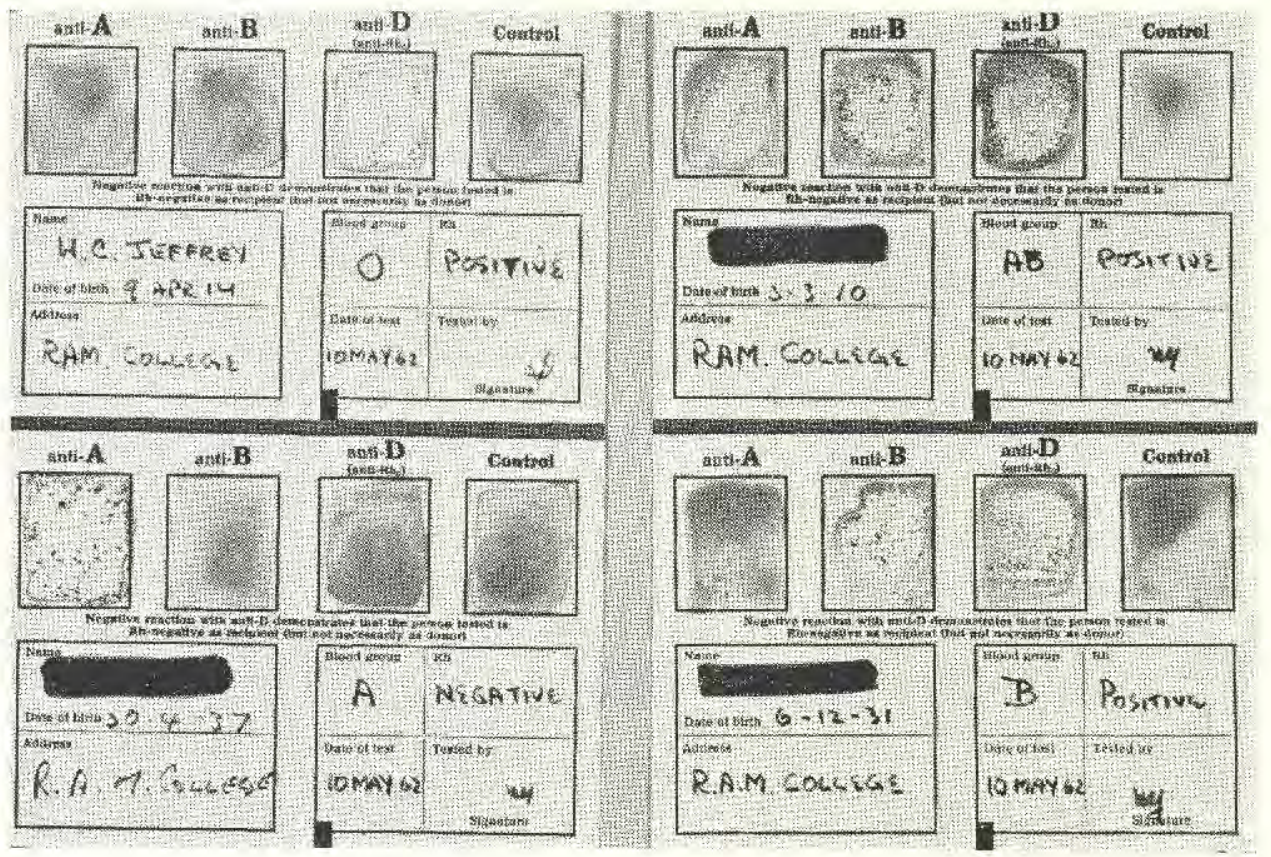

Fig. 2. Some results of grouping by Eldon Cards illustrating the clear-cut nature of the reactions and the method of documentation.

Keeping qualities. Dried Anti-A and Anti-B sera in ampoules have a life of at least two years; when reconstituted they remain active at room temperature for only a few hours, but for up to one week if refrigerated. In the latter circumstance, however, control testing with known A and B cells is deemed essential prior to use. Deterioration of grouping sera can be recognised only by testing with control cells of known groups.

Eldon cards are packed in moisture-proof metallic foil and it is claimed that the reagents will not deteriorate for some years (the expiry date at present is given as two 
years after manufacture) provided the storage temperature does not exceed $30^{\circ} \mathrm{C}$. $\left(76^{\circ} \mathrm{F}\right.$.). Deterioration of cards may be shown by the protective paper slip adhering to the reagents or the cellulose film on the card turning yellow.

There would appear to be no essential difference in the keeping qualities of dried antisera and Eldon cards, but the former require testing with control cells if reconstituted and kept refrigerated for further use. (This will have a bearing on the number of tests which can be performed, see below).

\section{Logistic aspects.}

Volume and weight. The Army blood grouping set includes six ampoules of each dried serum which will suffice for 180 tests provided the reconstituted sera are used within a few hours, or, if refrigerated, they are tested for potency against known cells each time they are used. Such a set weighs $510 \mathrm{~g}$. and has a volume of $934 \mathrm{cu} . \mathrm{cm}$. Sufficient Eldon cards (in boxes of ten) for 180 tests weigh $2,736 \mathrm{~g}$. and have a volume of $6,876 \mathrm{cu} . \mathrm{cm}$.

To perform approximately 1,000 groups would require a minimum of $6.6 \mathrm{lbs}$. contained in 0.2 cu.ft. for the Army set compared with $34 \mathrm{lbs}$ in a volume of $1.3 \mathrm{cu} . \mathrm{ft}$. in the case of the Eldon cards.

The Eldon cards are 5-6 times the weight and volume of the sets for the same number of groupings; the actual weight and volume, however, are of such an order as to be of little importance logistically.

Turn-over of stock piles. Dried grouping sera are in constant use and mobilisation stocks can be turned over readily. As the use of Eldon cards is not envisaged in peacetime, full turn-over could not be achieved; if they were stockpiled only a proportion could be used to train medical officers and laboratory technicians in their use.

Cost. The initial cost of Eldon cards would be some five times that of Army sets and maintenance of mobilisation stocks, because of the difficulty in turn-over, would be considerably more expensive. If, however, the cards provide a very much safer method of emergency grouping, cost must not be given much weight.

Availability. Materials for blood grouping sets are widely and readily available; Eldon cards are patented in most countries and are at present manufactured in Denmark.

Accuracy. In my hands Eldon cards have been satisfactory, they are easy to use, give clear-cut results and are rapid in action. These conclusions have been supported by all the pathologists and technicians who have worked with me on this subject and number of medical officers other than pathologists have been impressed with their potentiality. Grouping by the tile method is often difficult to read, and the test itself is considerably more complicated.

Figures derived from a variety of sources showing the percentage errors in blood grouping by simple methods are shown in the table.

The major series of tests with ABO sera show that the best results that can be obtained by simple cell grouping on a slide or tile have an error rate of at least 1 per cent in skilled hands, but most authorities quote error rates of around 10 per cent. The one large series of results with Eldon cards show an error rate of 0.06 per cent in $\mathrm{ABO}$ grouping, the minor series show a total of 0.7 per cent error when the test was performed by skilled personnel. It may be concluded that the accuracy of the Eldon card method is of a much higher order than tile-grouping with wet antisera, 
Table

Accuracy of blood grouping by simple methods

\begin{tabular}{|c|c|c|c|c|c|}
\hline Technique & Author & $\begin{array}{l}\text { Number of } \\
\text { Tests }\end{array}$ & $\begin{array}{l}\text { Experience of } \\
\text { Technicians }\end{array}$ & $\begin{array}{l}\text { Errors } \\
\text { in } \%\end{array}$ & Remarks \\
\hline \multirow{5}{*}{$\begin{array}{l}\text { Cell grouping } \\
\text { with Anti-A and } \\
\text { Anti-B sera } \\
\text { on slides } \\
\text { or tiles }\end{array}$} & Whitby (1953) & Unspecified & Unspecified & 10 & \multirow{4}{*}{$\begin{array}{l}\text { General experience, } \\
\text { 1939-45 War } \\
\text { General experience, } \\
\text { Korean War } \\
\text { General experience, } \\
\text { 1939-45 War } \\
\text { General routine } \\
\text { experience }\end{array}$} \\
\hline & & & Unspecified & 8 & \\
\hline & War Office (1957) & Unspecified & Unspecified & 19 & \\
\hline & $\begin{array}{l}\text { Boorman and } \\
\text { Dodd (1957) }\end{array}$ & Unspecified & $\begin{array}{l}\text { Skilled } \\
\text { Unskilled }\end{array}$ & $\left.\begin{array}{r}1 \\
10\end{array}\right\}$ & \\
\hline & Jeffrey (1962) & 383 & $\begin{array}{l}\text { Skilled } \\
\text { Unskilled }\end{array}$ & $\left.\begin{array}{r}1.3 \\
7.35\end{array}\right\}$ & $\begin{array}{l}\text { Trials in } \\
\text { B.A.O.R. }\end{array}$ \\
\hline \multirow{2}{*}{$\begin{array}{l}\text { Cell grouping } \\
\text { with Eldon Cards } \\
\text { (ABO group only } \\
\text { considered here) }\end{array}$} & Eldon (1955) & 6,591 & \multirow{4}{*}{$\begin{array}{l}\text { Mainly } \\
\text { Skilled } \\
\text { Unspecified } \\
\text { probably } \\
\text { skilled } \\
\text { Unspecified } \\
\text { probably } \\
\text { skilled } \\
\text { Skilled }\end{array}$} & 0.06 & \multirow{2}{*}{$\begin{array}{l}\text { Experience in } \\
\text { Denmark } \\
\text { Trials in U.K. }\end{array}$} \\
\hline & Pickles (1955) & 70 & & 0 & \\
\hline & Smith, et al (1955) & 85 & & 2.4 & Trials in U.K. \\
\hline & Stewart (1956) & 128 & & 0 & Trials in U.K. \\
\hline & Jeffrey (1962) & $\begin{array}{r}154 \\
84\end{array}$ & $\begin{array}{l}\text { Skilled } \\
\text { Unskilled }\end{array}$ & $\left.\begin{array}{r}0.65 \\
8.3\end{array}\right\}$ & $\begin{array}{l}\text { Trials in } \\
\text { B.A.O.R. }\end{array}$ \\
\hline
\end{tabular}

\section{Conclusions}

Eldon cards have the advantage over grouping with wet Anti-A and Anti-B sera in being easier to use, in reacting more rapidly, in that documentation is far less likely to lead to errors, in that results are more easily read and in being more accurate. In addition the cards have a panel for Anti-D grouping which has only a limited use for the Army in the field, but could be of considerable value in emergency civil defence work.

Disadvantages are only in the logistic field. The greater weight and volume of the cards is of such an order as to be really immaterial, but the cost of maintaining mobilisation stocks would be high and the availability of the cards under existing arrangements could well be imperilled on the verge of, or after the outbreak of, hostilities. Only early provision of adequate stocks for use on mobilisation, or manufacture in this country, could meet this problem.

With this proviso, it is considered that Eldon cards should be adopted as the method of choice for grouping under emergency conditions in the field and for rapid mobilisation pre-grouping if time and mán-power preclude conventional laboratory grouping techniques.

\section{REFERENCES}

Boorman, K. E. and DodD, B. E: (1957). Blood Groups Serology, Churchill, London. Crosby, W. H. (1955). Mil. med. 117. 354.

Eldon, K. (1955). Danish Med. Bull. 2, 33.

ELDON, K. (1956). Brit. med. J. 2, 1218.

JEFFEY, H. C. (1962). J. roy. Army med. Cps. 108, 114.

PICKLES; M. M. (1955). Brit. med. J. 2, 1561.

SMith; A. A., Coulson, A. and Webster, J. M. (1955). ibid, 2, 1450.

STEWART, P. D. (1956). ibid, $2,747$.

WhrtBY, L. E. H. (1953). History of Second World War, Medical Services, Surgery. H.M.S.O. London. 


\title{
A SIMPLE TEST FOR INFECTIOUS MONONUCLEOSIS
}

\author{
Major D. E. BRADFORD, \\ M.B., Ch.B., M.R.C.P.(Edin.), D.T.M.\& H., R.A.M.C. \\ Military Wing, Musgrave Park Hospital, Belfast*
}

Young adults with the so called ' glandular fever syndrome' are often seen in Army practice. Table 1 shows the admission rates per thousand to medical units over the past five years.

Table 1

Number of admissions of British Army personnel for glandular fever per 1,000 strength (A.M.D. Stats. 1966)

\begin{tabular}{|c|c|c|}
\hline Year & Males & Females \\
\hline 1961 & 0.8 & 2.2 \\
1962 & 0.9 & 2.6 \\
1963 & 0.6 & 1.1 \\
1964 & 0.7 & 2.3 \\
1965 & 0.8 & 0.9 \\
\hline
\end{tabular}

The disease complex can be caused by a number of conditions, the most important of which is infectious mononucleosis. A similar clinical state can occur in toxoplasmosis, listeriosis and infection with cytomegalovirus. The differentiation of infectious mononucleosis from these other diseases is sometimes not possible on clinical and haematological evidence alone, and rests on the estimation of the heterophil antibody titre (Paul and Bunnell 1932).

The Paul-Bunnell test, which has been in use for over thirty years, is considerably time consuming and there would seem to be a place for a rapid screening or diagnostic test for infectious mononucleosis.

Barrett (1941) described such a test using horse red cells in place of sheep cells and, by stabilizing these cells with formaldehyde, Hoff and Bauer (1965) found the test to be highly specific for infectious mononucleosis.

\section{Method}

The antigen consists of a 4 per cent saline suspension of formalized horse red cells. One drop of this suspension is added to one drop of the patient's serum on a glass slide. This is mixed at room temperature with a glass or plastic rod, rotated for two minutes and read for agglutination, within this time, against a dark background. A saline control is perfomed at the same time.

A positive result consists of coarse agglutination which usually develops within one minute. A fine granular pattern can often be seen with saline and control sera.

- Now British Military Hospital, Dhekelia, B,F.P.O. 53 


\section{Results}

During the recent influenza outbreak in Northern Ireland this test was used on thirteen patients who satisfied the clinical description of glandular fever. The results are detailed in Table 2.

Table 2

Thirteen patients with a glandular fever syndrome

\begin{tabular}{|c|c|c|c|c|c|c|c|c|}
\hline \multirow{2}{*}{ Case } & \multirow{2}{*}{ Sex } & \multirow{2}{*}{ Age } & \multicolumn{3}{|c|}{ Clinical Features } & \multirow{2}{*}{$\begin{array}{l}\text { Peripheral } \\
\text { Blood }\end{array}$} & \multirow{2}{*}{$\begin{array}{l}\text { Paul-Bunnell } \\
\text { Test }\end{array}$} & \multirow{2}{*}{$\begin{array}{c}\text { Horse Cell } \\
\text { Agglutination } \\
\text { Test }\end{array}$} \\
\hline & & & Fever & Glands & Spleen & & & \\
\hline 1 & $\bar{M}$ & 18 & + & + & - & + & 1 in 320 & + \\
\hline 2 & F & 25 & + & + & - & + & 1 in 80 & + \\
\hline 3 & $\mathrm{M}$ & 22 & + & + & + & + & 1 in 80 & + \\
\hline 4 & $\mathrm{M}$ & 22 & + & + & + & - & - & - \\
\hline 5 & $\mathbf{M}$ & 21 & $\begin{array}{l}+ \\
+ \\
\end{array}$ & $\begin{array}{l}+ \\
+ \\
\end{array}$ & - & $\begin{array}{l}+ \\
+ \\
\end{array}$ & 1 in 40 & $\begin{array}{r}+(14.1 .66) \\
+\quad(24.1 .66) \\
\end{array}$ \\
\hline 6 & $\mathbf{M}$ & 17 & + & + & - & - & - & - \\
\hline 7 & $\mathbf{M}$ & 21 & + & + & + & - & $\div$ & - \\
\hline 8 & $\mathbf{M}$ & 30 & + & + & - & + & - & - \\
\hline 9 & $\mathrm{M}$ & 27 & - & 4 & - & - & - & - \\
\hline 10 & $\mathrm{M}$ & 47 & + & + & - & - & $\div$ & $\therefore$ \\
\hline 11 & $\mathbf{M}$ & 22 & + & + & + & - & $\div$ & - \\
\hline 12 & $M$ & 27 & + & + & - & - & - & - \\
\hline 13 & $F$ & 15 & + & + & + & + & 1 in 1,280 & + \\
\hline
\end{tabular}

The peripheral blood film was regarded as positive if it showed any abnormal mononuclear cells.

The Paul-Bunnell tests were carried out on a guinea-pig kidney absorbed serum and titres of 1 in 40 and over were regarded as positive.

Case 6. Had classical rash of chicken pox. Glandular fever 3 months before.

Case 9. Had toxoplasmosis. Toxoplasma dye titre of 1 in 516.

\section{Comment}

This small series is insignificant when compared with that of Hoff and Bauer (1965), who found the test positive in 419 of a total of 426 patients suspected of having infectious mononucleosis, but does suggest that when the Paul-Bunnell is diagnostic then the horse cell agglutination test is positive.

This new test is simple and rapid and appears to be a useful screening test for infectious mononucleosis. With further use and experience it may well replace the Paul-Bunnell test.

Materials for this test are available from Denver Laboratories Ltd., Carlisle Road, London, N,W,9, as the DENCO-I.M, test kit which contains sufficient antigen for 40 tests. 


\section{REFERENCES}

Barrett, A. M. (1941). J. Hyg. 41, 330.

HoFF, G. and BaUER, S. (1965). J. Amer. Med. Ass. 194, 351.

Paul, J. R. and BunNell, W. W. (1932). Amer. J. Med. Sci. 183, 90.

\section{Order of St. John of Jerusalem}

Recent appointments to, or promotions in the Order, include:

As Commanders (Brothers)

As Officers (Brothers)
- Major-Generals, J. P. Douglas, O.B.E., Q.H.P., and K. F. Stephens, O.B.E., Q.H.S.

- Major-General R. M. Johnstone, M.B.E., M.C., Brigadier R. J. Niven, M.C. and Colonel K. P. Brown, M.B.E.

\section{Royal College of Surgeons of England}

Colonel J. M. Matheson, O.B.E., M.D., M.R.C.P., F.R.C.S.(Eng.\& Edin.), late R.A.M.C., has been elected as the Gordon Watson lecturer for 1967. 